\title{
VARIA 197 \\ Film and finance. An attempt at a statistical comparison of the attendance results and ratings of Polish films in the years 2012-2015[1]
}

\author{
MARCIN ADAMCZAK \\ Institute of Cultural Studies
}

Adam Mickiewicz University in Poznań

AGNIESZKA ORANKIEWICZ

faculty of Economics and Sociology

University of Lodz

\begin{abstract}
AвSTRACT. Adamczak Marcin, Orankiewicz Agnieszka, Film and finance. An attempt at a statistical comparison of the attendance results and ratings of Polish films in the years 2012-2015. „Images” vol. XXIII, no. 32. Poznań 2018. Adam Mickiewicz University Press. Pp. 197-209. ISSN 1731-450X. DOI 10.14746/i.2018.32.16.

The article is an attempt to use essential statistical tools for analysis of market performance of films and its aesthetical judgements made by film critics and fans. The authors describe differences between evaluations of films by professional and non-professional viewers, correlations between market performance and artistic merit and impact of level of public support for success and quality of movies. The material for analysis are Polish films in cinema distribution between 2012 and 2015.
\end{abstract}

KEYWORDS: Polish film market, film economy, film financing, film and statistics

\section{Introduction}

In 1974 Edward Zajiček published an article titled "Komercjalizacja... zachęta... statystyka" [Commercialization... incentive... statistics] in the Polish film journal Kino.[2] In his text, Zajiček, a scholar of the economic history of cinema, proposed an original approach based on the application of statistical tools to the analysis of attendance results and quantified critical ratings. From today's perspective, some of the preoccupations of that article, which could be summed up as attempts at finding incentives that would help interest filmmakers in making money and thus render socialist cinema more profitable, are a thing of the past. However, the application of statistics to the analysis and comparison of attendance results, critical ratings and audience preferences seems to remain intriguing and deserving of further exploration. This article is the result of preliminary research based on chosen statistics from recent years, and is motivated by the will to continue Edward
Zajiček's school of thought. It is the authors' intention to open discussion on the topic by outlining the possibilities offered by the application of statistical tools to box office analysis.

Our article also aims to argue the purposefulness of incorporating at least some amount of statistics into the study of film. Until this moment the statistical approach has remained the domain of professionals from the film industry, the majority of whom are most likely distributors. Sławomir Salamon, one of the

[1] Publikacja finansowana w ramach programu Ministra Nauki i Szkolnictwa Wyższego pod nazwą Rozwój 2b, Narodowy Program Rozwoju Humanistyki, w latach 2016-2019. The work was supported by the European Regional Development Fund - Project "Creativity and Adaptability as Conditions of the Success of Europe in an Interrelated World" (No. CZ.02.1.01/o.o/o.o/16_o 19/0000734)

[2] E. Zajiček, Komercjalizacja..., zachęta..., statystyka, "Kino" 1974, no 8, pp. 31-39. 
198

VARIA

most experienced Polish distributors, who has been successfully active in this market sector for over a quarter of a century, is a mathematician by training. "Knowledge of mathematics was very helpful when I founded the boxoffice. pl database, which is, in a way, a mathematical model. It was also what led me towards a professional interest in cinema. In the late 1980s, Agnieszka Holland came to Poland with the film To Kill a Priest (Zabić księdza). At that time I was already involved in organizing film screenings, and I toured with her around Poland with one copy of the film. One day, on our way to Gorzów, we had a conversation about what I could do in the film industry, since I did not have the temperament of a director and I could not become an actor either; Agnieszka said: maybe you could work in distribution? It is all about numbers and so boring", Salamon recalls today.[3]

The authors of this article believe that numbers, at least in the context of cinema and the film market, are by no means boring. Quite to the contrary, in the process of writing this text and examining various sets of statistical data, we often felt as if we were working on absorbing puzzles in a search for observable patterns and convincing explanations. We are convinced that this type of research perspective, which we only preliminarily explored in this article, could become a compelling "detective adventure" at the intersection of mathematics and film studies.

\section{Methods}

The study included Polish feature films released in the years 2012-2015. We quantified the reviews from critics and film studies experts regularly published in the journal "EKRANy" in a column titled "Loża boczna" [Side box]. Numerical ratings from viewers were sourced

[3] As cited in M. Adamczak, $W$ cieniu bomby. O dystrybucji filmowej, dwutygodnik, 219/2017. <http://www.dwutygodnik.com/artykul/7334-w-cieniu-bomby-o-dystrybucji-filmowej.html> [access: 20.02.2018].

[4] J. Płażewski, Żeby moneta gorsza nie wypierała lepszej, "Kino" 1994, nr 7-8, pp. 4-6. from the website filmweb.pl. We also used data collected by the Polish Film Institute and the database boxoffice.pl.

\section{Objectives}

The success of a film is an ambiguous concept - it can be defined in several manners. Success can be understood as receiving awards from the jury of an important festival, or as excellent attendance results followed by a stream of cash that flows towards the producer and distributor. Success can also mean enthusiastic reviews from critics or vigorous praise from so-called "regular viewers". Moreover, these different types of success do not have to be mutually exclusive, although it often happens this way and it is indeed a common assumption that festival awards and box office queues rarely both happen for the same picture. The problem of film evaluation and the different categories of success becomes even more complex if we include the additional factor of time. How many Golden Palms, Lions and Bears had been awarded to films now completely forgotten, while movies that today have become part of the cultural cannon were glossed over? In the case of how often canonical works' first contact with audiences, and festival audiences was marked by booing, ironic comments or even, as the legends of the history of cinema have it, throwing objects at the screen? One example of this kind of initial reception is the famous anecdote about the Cannes premiere of The Adventure by Michelangelo Antonioni in 1960. Today, we often find it amusing to browse through archive issues of film journals and read the critical opinions expressed in them, which highly praise works that today are considered mediocre or trash the contemporary classics freshly after their release. It is worth opening an archive copy of the journal Kino from 1994 and reading the commentaries written after Three Colors: Red lost at Cannes to Pulp fiction, the second movie of the unknown young American filmmaker Quentin Tarantino.[4]

The problem of evaluating the quality of a work belongs not only to the domains of film 
studies, poetics, aesthetics or historical reflection on the mechanisms that shape and reshape the cannon. This question is also relevant for justifying the spending of public funds in the context of the current system of financing film production in Poland. Today the debate about public financial support for Polish cinema is, thankfully, not as heated as the discussion that took place at the beginning of the twenty-first century, when the new Act on Cinematography was introduced. However, from time to time, there are voices which do not question whether cinema should be subsidized at all, but ask to determine which films should be supported and when such support is justified.

In this preliminary study we aimed to answer three research questions. The first objective was to determine if the reviews from critics and viewers (or rather active but not professional film fans) are convergent, similar or divergent. The second question we posed was whether high ratings from critics contributed positively to a film's attendance results, or if they were neutral or even, in accordance with popular intuitions, did not favor financial success. The third problem studied concerned the relationship between the participation of the Polish Film Institute in the financing of a given title and the picture's quality (based on reviews from critics) or its success among a broader audience (translating to financial success)?

Critics and users: reviews from professional and nonprofessional film lovers

Undoubtedly, the judgments expressed by critics and viewers are one of the measures of a film's success. Nevertheless, it should be noted that the review of a film is a very subjective measure that reflects the viewer's individual experience. The reviewers are guided by different criteria and have varying tastes and experiences.

Edward Zajiček assumed that the viewers vote for a film by going to the cinema and buying tickets.[5] However, today the determinants affecting audience behaviors seem more complex. The choice to go to the cinema to see a particular film is more often the result of advertising and marketing than a rational decision based on knowledge. Today, the purchase of a cinema ticket is an evaluation of a well-targeted marketing strategy and the resultant of the size of the PR and advertising budget rather than a judgement about the film itself. If we wanted to know viewers' opinion about the film product we should ask them once they have consumed it, that is - after they watch it.

For the purpose of these considerations, we gathered reviews from the website filmweb.pl. Apart from writing a review, the users of the website can award a rating on a scale from 1 to 10. When analyzing the opinions of viewers, we should bear in mind that they do not constitute a homogenous community. They present differing levels of cultural education, varying tastes and genre preferences. Film viewers are more eager to review and rate movies that are controversial, that they did not like, or ones with which they were thrilled. It is rarer for them to rate films that did not make a strong impression. Thus, there are mostly extreme ratings, which are later averaged in the total score.

The opinions of critics are difficult to quantify, as they are usually descriptive. In the journal "EKRANy", critics and film studies experts award the reviewed films notes on a scale from 1 to 5 , which allowed us to perform a quantitative analysis of the critical opinions. For the purpose of the conducted analysis, we gathered and quantified the opinions of critics published in the "EKRANy" journal which were related to films that premiered in the years 2012-2015. Not all films screening at that time were reviewed. In the analyzed period, critics and experts reviewed a total of 67 films. The majority of awarded notes were within the middle range of the scale, between 2.51 points and 3.5 points. Extreme notes, lower than 1.51 points or higher than 4.5 points, were the least frequent. It is worth noting that the distribution of ratings from critics is close to normal distribution. [6]

[5] E. Zajiček, op.cit.

[6] Normal distribution - the most common distribution of empirical variables, according to 


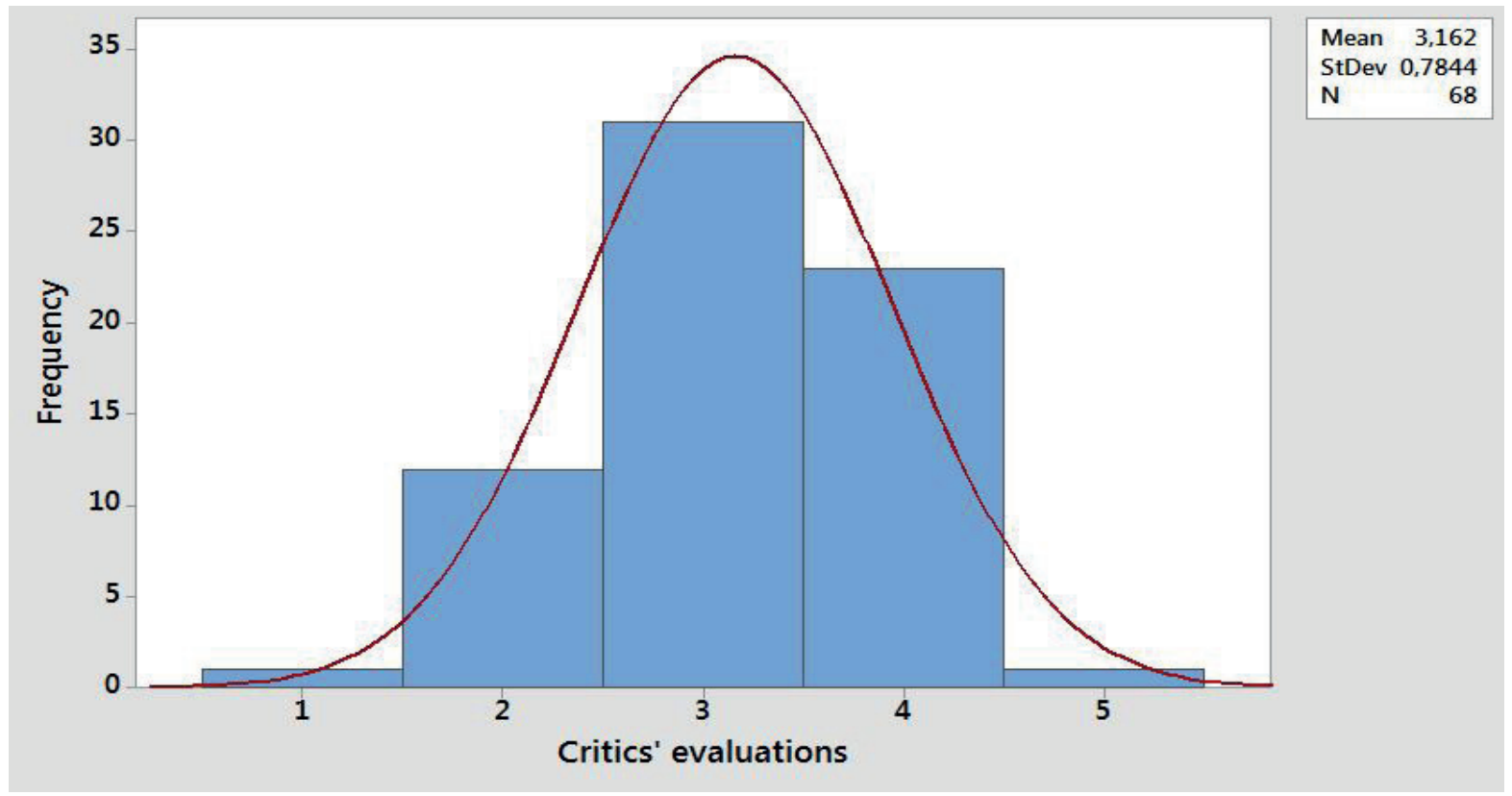

Fig. 1. Distribution of ratings awarded by critics to 67 films reviewed in the "EKRANy" journal

This interesting regularity is in accordance with the findings expressed in Edward Zajiček's article published over forty years ago in the context of a completely different market and production reality and a film culture in which critics held a different status.[7]

The distribution of ratings is shown in Figure 1.

Since the ratings on the filmweb.pl website and in "EKRANy" are awarded according to different scales, in order to enable comparison, they were represented on a scale from 1 to 100. The correlation coefficient between the two groups of ratings was 0.514 , which means that the studied films achieved similar results among both groups. The opinions of viewers and critics about the quality of the reviewed films were not exactly the same, but rather convergent. This result counters the thesis according to which the "mass" viewers could not tell a good film from

which many natural phenomena are organized. It is characteristic for phenomena, the size of which constitutes the sum or average of several small random factors. The normal distribution diagram has the form of a bell-shaped curve.

[7] E. Zajiček, op.cit. a bad one and thus would be prone to prefer mostly films that are easily digestible, simple and pleasant. The high correlation between the ratings may lead to two conclusions. The first one could be that the Polish audience is composed of educated and well-aware viewers, so their tastes are concurrent with those of critics. The second conclusion is that perhaps only part of the audience decided to express its opinion through voting online and these were specific viewers who are particularly interested in film, have good taste and a vast knowledge about cinema. These conclusions are not mutually exclusive; although, the second one would seem more likely. It should be noted that in the analysis we did not take into account the number of persons who voted for each film, and this may be an important variable, considering the dynamics of the impact of small fan groups on the total score in the case of films with smaller audiences and smaller vote numbers. Either way, it seems to us an important observation that there is a far-reaching convergence between ratings awarded by fans and critics and experts, or, in other words, between by professional and nonprofessional film lovers. 
Table 1. The 10 films for which the ratings from critics and viewers are most convergent

\begin{tabular}{|c|c|c|c|c|c|c|}
\hline No. & Title & $\begin{array}{l}\text { Release } \\
\text { year }\end{array}$ & Director & $\begin{array}{l}\text { Filmweb } \\
\text { rating }\end{array}$ & $\begin{array}{l}\text { “EKRANy" } \\
\text { rating }\end{array}$ & $\begin{array}{l}\text { Absolute } \\
\text { difference }\end{array}$ \\
\hline 1 & Jeziorak (Waterline) & 2014 & Michał Otłowski & 66 & 66.0 & 0.0 \\
\hline & $\begin{array}{l}\text { Jak całkowicie zniknać (How } \\
\text { to Disappear Completely) }\end{array}$ & 2014 & Przemysław Wojcieszek & 47 & 47.6 & 0.6 \\
\hline 3 & $\begin{array}{l}\text { Anatomia zła (Anatomy of } \\
\text { Evil) }\end{array}$ & 2015 & Jacek Bromski & 61 & 60.0 & 1.0 \\
\hline 4 & $\begin{array}{l}\text { Być jak Kazimierz Deyna } \\
\text { (Being like Deyna) }\end{array}$ & 2013 & Anna Wieczur-Bluszcz & 62 & 63.4 & 1.4 \\
\hline 5 & Obywatel (Citizen) & 2014 & Jerzy Stuhr & 57 & 55.0 & 2.0 \\
\hline 6 & Nowy Swiat (The New World) & 2015 & $\begin{array}{l}\text { Elżbieta Benkowska, Michał } \\
\text { Wawrzecki, Łukasz Ostalski }\end{array}$ & 52 & 54.2 & 2.2 \\
\hline 7 & Wenus w futrze (Venus in Fur) & 2013 & Roman Polański & 73 & 75.6 & 2.6 \\
\hline 8 & Pod mocnym aniołem (Angel) & 2014 & Wojciech Smarzowski & 69 & 66.2 & 2.8 \\
\hline 9 & Nieulotne (Indeleble) & 2013 & Jacek Borcuch & 49 & 52.0 & 3.0 \\
\hline 10 & $\begin{array}{l}\text { Wałęsa. Człowiek z nadziei } \\
\text { (Walesa: Man of Hope) }\end{array}$ & 2013 & Andrzej Wajda & 63 & 66.2 & 3.2 \\
\hline
\end{tabular}

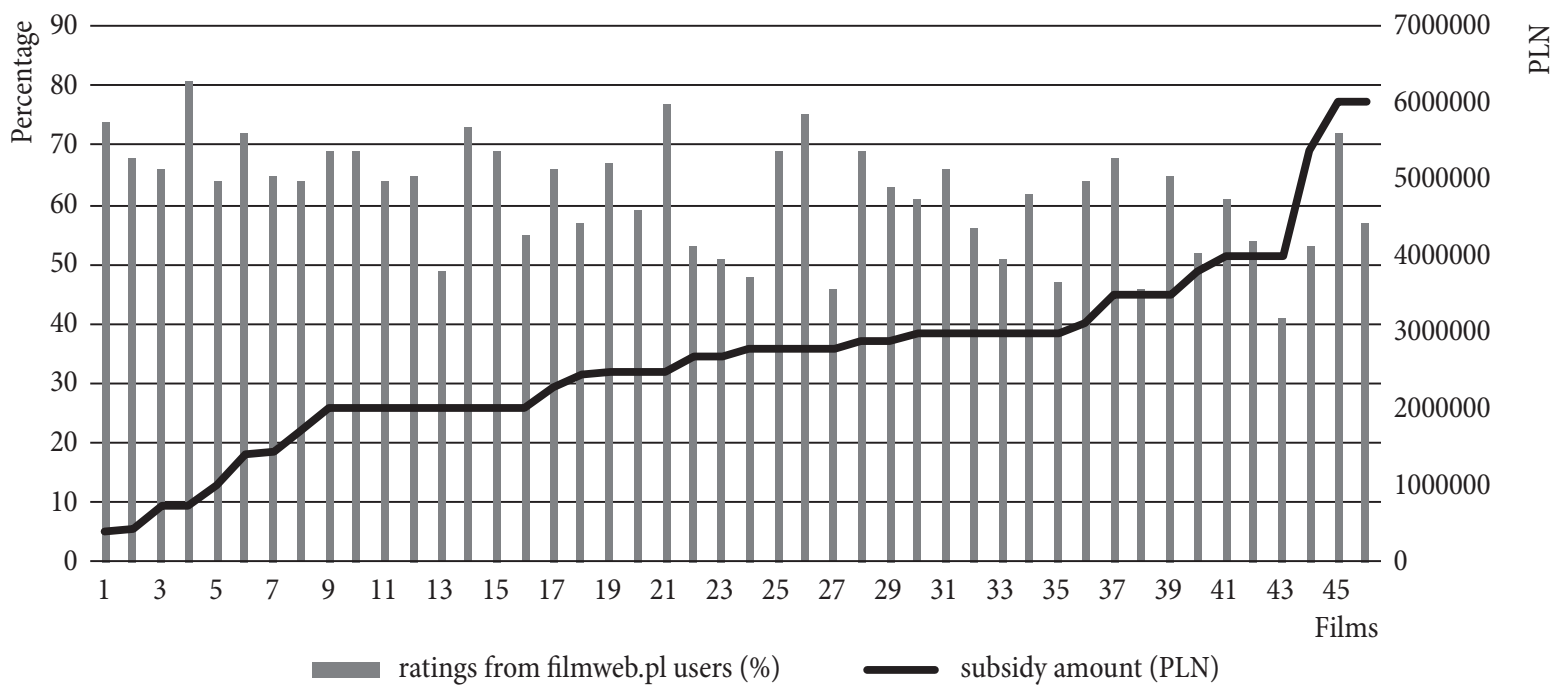

Fig. 2. Comparison of ratings awarded by critics and viewers to the sample of 67 films released in the years 2012-2015 that were reviewed in the "EKRANy" journal

In the following stage of our research we distinguished two sets from the analyzed group of pictures: films for which the ratings from professional and nonprofessional viewers had the highest degree of convergence and films that received the most discrepant ratings from the two groups of viewers. We wanted to see if we could discern regularities when comparing the two sets of films and draw a hypothesis as to the sources of the differences. 
202

VARIA

Table 2. The 10 films which received the most divergent ratings from critics and viewers

\begin{tabular}{|c|c|c|c|c|c|c|}
\hline No & Film title & $\begin{array}{l}\text { Release } \\
\text { year }\end{array}$ & Director & $\begin{array}{l}\text { Filmweb } \\
\text { rating }\end{array}$ & $\begin{array}{l}\text { “EKRANy" } \\
\text { rating }\end{array}$ & $\begin{array}{c}\text { Absolute } \\
\text { value of } \\
\text { difference }\end{array}$ \\
\hline 1 & Zbliżenia (Close-ups) & 2014 & Magdalena Piekorz & 60 & 30,0 & 30.0 \\
\hline 2 & Córki Dancingu (The Lure) & 2015 & Agnieszka Smoczyńska & 49 & 76.0 & 27.0 \\
\hline 3 & $\begin{array}{l}\text { Serce serduszko (The Heart and } \\
\text { the Sweetheart) }\end{array}$ & 2014 & Jan Jakub Kolski & 68 & 45.0 & 23.0 \\
\hline 4 & Chemia (Chemo) & 2015 & Bartek Prokopowicz & 63 & 40.0 & 23.0 \\
\hline 5 & Obława (Manhunt) & 2012 & Marcin Krzyształowicz & 66 & 87.6 & 21.6 \\
\hline 6 & 11 minut (11 minutes) & 2015 & Jerzy Skolimowski & 46 & 66,6 & 20.6 \\
\hline 7 & Jesteś Bogiem (You Are God) & 2012 & Leszek Dawid & 68 & 87.6 & 19.6 \\
\hline 8 & $\begin{array}{l}\text { Bilet na księżyc (One Way Ticket } \\
\text { to the Moon) }\end{array}$ & 2013 & Jacek Bromski & 65 & 45.8 & 19.2 \\
\hline 9 & Sąsiady (Neighborhooders) & 2014 & Grzegorz Królikiewicz & 41 & 60.0 & 19.0 \\
\hline 10 & W ukryciu (In Hiding) & 2013 & Jan Kidawa-Błoński & 55 & 36.0 & 19.0 \\
\hline
\end{tabular}

Our general conclusion is that convergent ratings from viewers and critics apply mostly to films that averaged within the middle range of the rating scale. The highest level of convergence was recorded for the films Waterline (Jeziorak) by Michał Otłowski (the average scores from critics and viewers were perfectly convergent at 66 points) and How to Disappear Completely (Jak całkowicie zniknać) by Przemysław Wojcieszek (the average scores from viewers and critics were almost identical, at 47 and 47.6 points). In terms of their substance, these pictures appear to have little in common. Waterline is an example of well-made Polish genre crime cinema, while Wojcieszek's nonlinearly narrated film belongs to the domain of arthouse cinema. It seems that the possible explanations for the high convergence in these two cases will be different, and, in general, similarities in audience and critic ratings may occur for different reasons for a few different types of films. In the case of Otłowski's film, it appears that the convergence between the ratings from professional and nonprofessional viewers is observed in the context of good film-making and decent "middlebrow cinema" that is ably nar- rated but conventional in terms of plot (which would be also the case of titles 3 and 4 from the above set). In the case of Wojcieszek's picture, we must underline the very small number of reviews on the filmweb.pl website, which corresponds with the minuscule amount of cinema goers the film attracted. The film was rated by 1,171 users (meanwhile Otłowski's picture received reviews from almost twenty times as many people $-20,262$ ). The only film from the list to receive an even smaller number of ratings was The New World (Nowy Swiat) with 699 votes. We can hardly call the audience of the pictures by Wojcieszek and by Benkowska, Ostalski and Wawrzecki "mainstream". It can be assumed that the niche audience is made up by a specific group of people - people who are interested in this kind of cinema, perhaps some of them being industry professionals or cinephiles with a level of competence close to that of professional viewers. The third group of that can be distinguished from the list of ten films with most convergent ratings among viewers and critics contains movies by celebrity-status directors: Roman Polański, Andrzej Wajda and Wojciech Smarzowski, as well as Jerzy Stuhr - 
an average director at best, but one who draws his celebrity status from being a known actor.

When analyzing the list, we noticed one more interesting phenomenon, which can cast some doubt on the reliability of one of the categories analyzed further in this article: audience numbers and the film's financial success. As we mentioned, Waterline was reviewed by 20,262 users of the website, while How to Disappear Completely received notes from only 1,171 people. Meanwhile, the cinema audience numbers for these two films reached 22,369 and 1,861 viewers, correspondingly. [8] Such a high proportion between the number of tickets sold and number of online reviews, if we assume that it is unlikely that almost every person exiting the screening felt compelled to rate the film they had just watched on the above-mentioned website, shows how approximate are the profitability figures based only on cinema audience numbers without taking into account profits from TV distribution and DVD sales (which are more difficult to measure). In our opinion this demonstrates the scale of pirate distribution, which is still hard to pinpoint for those studying the film market in Poland.

The greatest divergence between ratings from professional and nonprofessional viewers was observed in the case of the film Close-ups (Zbliżenia) by Magdalena Piekorz (6o points on average from fans and 30 points from critics). Another film with highly divergent scores was The Lure (Córki Dancingu) by Agnieszka Smoczyńska. The musical about mermaids was evaluated much more favorably by critics and experts ( 76 points), while gaining decidedly lower ratings from viewers (49 points). Interestingly, these discrepancies are related mainly to films for which the ratings from critics were situated either in the upper (over 70 points) or lower (30-40 points) ranges of the scale.

This list is also interesting because while we do find two quite different films at its top, the divergent rating vectors in these two cases appear to broaden the knowledge we gained from the previously discussed first data set. Magdalena Piekorz's film, which aspires to be artistic, is an extremely inept work. Many scenes in
Close-ups resemble an unintended pastiche of artistic cinema, or even self-parody; from the first shots, in which a mother tells her artist daughter that she is very talented but the world underappreciates her and she must believe in herself, to the sequence, in which the main protagonist sublimates her inner anxiety through sculpting in a bout of untamed creative frenzy. Meanwhile, The Lure is an excellent film, which takes creative risks, and while it does have certain shortcomings in terms of plot construction, it thoroughly impresses with its original imagination, escaping simple classifications into genre cinema and artistic cinema and intriguing both visually and musically. Agnieszka Smoczyńska employs conventions drawn from the musical genre and camp esthetics to tell a story of two murderous mermaids fished out from the Vistula river, projecting them against a discretely traced backdrop of 1980 os Warsaw. The Lure's greatest strengths include its music, tone, rhythm and the young performers in the roles of teenage mermaids.

The study of this second list dictates a cautious approach towards the conclusions that come to mind after reading the first list and seeing the relatively high correlation between ratings from nonprofessional and professional viewers. The reader can rest assured: the people who earn their living writing about film appear to have slightly higher professional competences to review films than "the common man" and the years they spent in graduate film studies programs we find in their résumés have not been for nothing. We would like to venture the thesis that the two discussed lists demonstrate that professional and nonprofessional viewers have a similar level of competence when judging mostly well-made middlebrow genre cinema, but nonprofessional viewers have great difficulty in distinguishing between good and bad art cinema. And it is here, in making this distinction and separating the artistic wheat from pretentious pseudoartistic chaff, that the key role of critics and film experts appears to lie.

[8] Results quoted after the box-office.pl database. 
We are of the opinion that among the 10 cases of divergent opinions between the website users and critics, the proper judgement lies with the critics. The only exception seems to be number 8 with One Way Ticket to the Moon by Jacek Bromski - a nostalgic venture into the times of the People's Republic of Poland that was judged very harshly by the critical community. [9] In the remaining cases we venture the following hypotheses: the nonprofessional viewer remains much more susceptible to sentimental subjects that constitute a contemporary version of "tearjerkers" (numbers 3,4 , and to some extent also 10), and in light of averaged scores, the nonprofessional viewer remains less competent than critics and experts when it comes to judging films that have original unconventional form. Having said this, the narration of the films that are not as well received by nonprofessional critics does not have to achieve the summits of innovation and sophistication. Skolimowski's 11 minutes (11 minut) has predecessors in the works of directors like Alejandro González Iñárritu or Fernando Meirelles, and the very good Manhunt (Obława) is a consequent attempt by Krzyształowicz at the mindgame film convention known from world cinema. You Are God (Jesteś Bogiem) seems to be yet a separate case, in which the lower average score from viewers could have been impacted by the fact that a large proportion of former

[9] Perhaps one factor that played a role in the severe judgment of the film by Bromski, who is the head of the Polish Filmmakers Association, was the dissatisfaction of the filmmakers' community with the film being voted best picture at the Gdynia festival, as well as the controversies around the absence of Bromski's previous film, Uwikłanie (Entanglement), at the Gdynia competition in 2011, in the first year of Michał Chaciński's term as the festival's artistic director. The community sided with Chaciński. These are of course speculations; although, it should be noted that even if the film is not an outstanding one it was judged too harshly.

[10] In off-the-record conversations some distributors like to say about this phenomenon that "sometimes critics like really weird films". fans of the band Paktofonika participated in the vote, expressing that their vision of the tragic history of the group and its leader was not necessarily identical with the artistic choices made by Leszek Dawid and Maciej Pisuk.

In the case of the very visible discrepancy related to Smoczyńska's film, as glaring as the outfits worn by her protagonists, what appears to have occurred is the phenomenon of films that are dubbed "critics' pets". Such films are enthusiastically received among professional viewers who watch hundreds of films per year and yearn for a change more than other audiences.[10]

At the end of the discussion of this list it is worth mentioning one more interesting fact the two films at the its top, Close-ups (Zblizzenia) and The Lure (Córki Dancingu), had the same distributor. The company Kino Swiat is one of the largest in the Polish distribution sector, often dominating the annual market share rankings. Its employees' expertise in the distribution trade is unquestionable, which is proved by the fact that they were able to attract over 15, ooo cinema-goers to a film like Close-ups. The company is also recognized as the Polish distributor that most frequently designs its PR campaigns (trailer, poster) to suggest they are selling a slightly different picture than in reality and promise a slightly different experience than the one the viewer could actually expect. An example of such a strategy can by promoting the film All about My Parents (Pani z przedszkola) by Krzyształowicz as a regular comedy, and advertising The Lure as a normal musical set in the colorful world of 1980 os dancing halls. One of the factors favoring the disappointment of nonprofessional viewers expressed in the low ratings of Smoczyńska's film could have been the letdown resulting from the dissonance and missed expectations which have their source in an advertising campaign that is on purpose slightly misleading.

\section{Signs of attendance success}

An important factor that can help judge a film's financial success is its declared income. 
The numbers analyzed here should not be treated as the total profits grossed by the picture. The data presented below are not complete, as they present only income from cinema tickets, while omitting other distribution channels and sources of income. Audience numbers and a film's income are very strongly correlated, which means that ticket prices in different cinemas and particular screenings are similar and the audience numbers translate directly to income. Based on the performed analyses it can be claimed that there is a higher correlation between the ratings from filmweb.pl users and audience numbers and box office income than between ratings from critics and financial and attendance results.

However, in both cases, the relationship is not very strong. Nor can we confirm the intuitions that high critical ratings predict low box office and attendance, or that, in other words, films that are liked by critics are usually not popular among the mass audiences. These kinds of hypotheses were not confirmed by reality, as (despite the above-mentioned phenomenon of "critics' pets") the correlation is actually positive.

From the above considerations, another question emerges: what else apart from the opinion of other viewers and experts impacts the financial success of a film? A film's success can be, of course, influenced by various factors. Among them are certainly the film's budget, and especially the amount of funds devoted to advertising and marketing, the participation of a star actor that attracts audiences, the genre of the film, and the number of copies that are sent to distributors, which impacts the film's availability. It is possible to carry out analyses of the profitability of particular genres, the importance of the number of copies and the relationship between budget size and results. The impact of the participation of celebrity actors on profits would be difficult to quantify. It seems that the amount of funds spent on promoting the film is of great significance. The analysis of the impact and efficiency of spending would be undoubtedly a valuable study venture; however, this data most often constitutes the trade secret of the distributors, and, moreover, there would always be doubts as to their credibility.

\section{Support from public funds and the film's success}

The Polish Film Institute is in charge of the public funds devoted to the support of Polish cinematography. The Institute, as a public institution, which receives funds from five types of market entities pursuant to the 2005 Act on Cinematography, is tasked with implementing specific public goals. These include supporting Polish cinematography, cultural education and creating conditions for universal access to the achievements of the art of cinema. These goals are obtained through granting subsidies, loans and sureties to producers. The criteria for awarding this support include the anticipated effects of the planned project.[11]

The decision to grant support to the production of a given film is issued by the head of the Institute based on the recommendations of expert commissions. It should be noted that the experts give their opinions based on the screenplay and other documents delivered by the applicant, before production begins. The final artistic result remains, of course, unknown, at the time the decisions about financing are made. Despite the complex process of evaluation and carefully selected expert commissions, the fact that an application received good notes and was awarded support does not guarantee the quality of the film to be produced. Factors that decide about financing include also components other than quality, for instance, matters impacting its so-called "strategic assessment".

Public opinion, artistic success, as well as the economic results achieved by a film could all justify the intervention of the state and public financing in the cultural sector. So is the financial success a derivative of the fact that the film received support from public funds? This question can also be phrased from a different

[11] Act of 30 June 2005 on cinematography, "Dziennik Ustaw" 2005, No. 132, item 1111, article 22, point 3 . 
Table 3. The 10 films released in the years 2012-2015 with the greatest commercial and attendance success

\begin{tabular}{|c|c|c|c|c|c|c|}
\hline No. & Title & $\begin{array}{l}\text { Distribution } \\
\text { company }\end{array}$ & $\begin{array}{l}\text { Year of } \\
\text { release }\end{array}$ & Income & Attendance & $\begin{array}{l}\text { Subsidy from } \\
\text { the Polish } \\
\text { Film Institute }\end{array}$ \\
\hline 1 & Listy do M. 2 (Letters to M. 2) & KINO ŚWIAT & 2015 & 54075180 & 2968392 & $\mathrm{NO}$ \\
\hline 2 & Bogowie (Gods) & NEXT FILM & 2014 & 40273065 & 2265361 & TNO \\
\hline 3 & Miasto 44 (Warsaw'44) & KINO ŚWIAT & 2014 & 26046065 & 1753309 & YES \\
\hline 4 & Jesteś Bogiem (You Are God) & KINO ŚWIAT & 2012 & 25152492 & 1445616 & YES \\
\hline 5 & W ciemności (In Darkness) & KINO ŚWIAT & 2012 & 20293539 & 1200477 & YES \\
\hline 6 & Jack Strong & VUE MOVIE & 2014 & 20981153 & 1180010 & YES \\
\hline 7 & Drogówka (Traffic Department) & NEXT FILM & 2013 & 19338924 & 1025407 & YES \\
\hline 8 & $\begin{array}{l}\text { Watęsa. Człowiek z nadziei (Wa- } \\
\text { lesa: Man of Hope) }\end{array}$ & VUE MOVIE & 2013 & 15413351 & 970520 & YES \\
\hline 9 & Pod Mocnym Aniołem (Angel) & KINO ŚWIAT & 2014 & 16284472 & 884607 & YES \\
\hline 10 & Disco Polo & NEXT FILM & 2015 & 16198826 & 878955 & $\mathrm{NO}$ \\
\hline
\end{tabular}

perspective, namely whether the involvement of the Polish Film Institute is a circumstance that allows one to expect that a film will attract crowds to the cinemas. It turns out that subsidization (although it undoubtedly contributes to better conditions for the film's production) is not a necessary condition for a film's financial success. In the studied period the best financial results were achieved by Maciej Dejczer's Letters to M. 2 (Listy do M. 2), which is a typical commercial picture with no support from public funds. This situation seems to echo the common opinion that there exists a dichotomy between popular commercial genre films, usually financed by private producers, on the one hand, and sophisticated niche artistic works supported by state patronage agencies and public funds.

Nevertheless, if we look at the broader sample of the ten highest grossing films in the studied period, we see that the production of the majority of these films was supported by the Polish Film Institute, so public funding was involved.

It is surprising to see the film Disco Polo directed by Maciej Bochniak make this list. Its ratings from filmweb.pl users were not high (51 points), but the young director's debut was one of the ten films with best attendance results as well as highest income. The opinions of critics in this case better match the success of the film. Their ratings were better ( 71 points). The explanation of the popularity of Bochniak's film may lie in the broader cultural phenomenon of disco polo music, which still remains immensely popular, while at the same time being perceived as a type of entertainment that is kitshy and in bad taste. Perhaps the critics, confident in their judgements, were not afraid of being seen as having bad taste, which would be a good sign of the autonomy of film criticism. However, the quantified reviews from critics in this particular case do not necessarily have to be representative in general.

This thread leads to the question if the amount of funds awarded by the Polish Film Institute to the production of a given film based on the recommendations from experts is related to the later rating of these films by a different group of experts (critics and film studies experts) and by the main target group (the nonprofessional broad audience). In other words, whether the experts can accurately predict a given project's attendance or financial results before it is produced. 
Table 4. The 10 films with highest adjusted income

\begin{tabular}{lccc}
\hline \multicolumn{1}{c}{ Film title } & $\begin{array}{c}\text { Release } \\
\text { year }\end{array}$ & \multicolumn{1}{c}{ Director } & $\begin{array}{c}\text { Income adjusted for } \\
\text { subsidy amount }\end{array}$ \\
\hline Bogowie (Gods) & 2014 & Lukasz Palkowski & 38271552 \\
Jesteś Bogiem (You Are God) & 2012 & Leszek Dawid & 22652492 \\
Miasto 44 (Warsaw '44) & 2014 & Jan Komasa & 20045517 \\
Jack Strong & 2014 & Władysław Pasikowski & 17181153 \\
Pod mocnym aniołem (Angel) & 2014 & Wojciech Smarzowski & 13284472 \\
Moje córki krowy (These Daughters of Mine) & 2015 & Kinga Dębska & 11268600 \\
Wałęsa. Człowiek z nadziei ((Walesa: Man of Hope) & 2013 & Andrzej Wajda & 9413351 \\
Obywatel (Citizen) & 2014 & Jerzy Stuhr & 5902085 \\
Chemia (Chemo) & 2015 & Bartek Prokopowicz & 3372168 \\
Karbala & 2015 & Krzysztof Łukaszewicz & 3157555 \\
\hline
\end{tabular}

If we treat the ratings from critics as a measure of a film's success in terms of substance, the analysis we carried out proves that there is practically no relationship between the amount of funds awarded by the Polish Film Institute and high critical ratings. This applies also to ratings from viewers. Also with this group, there is also no relationship between the amount subsidized from the Institute and the audience's reviews.
This data set, however, is of limited usefulness. The aim (which is, in our opinion, rightly justified) of the Polish Film Institute was, from its beginning, to support popular genre cinema, which does not always get the highest notes from critics and is not always artistically impressive, but builds a basis for a well-functioning film industry. This is why the next list may prove more pertinent.

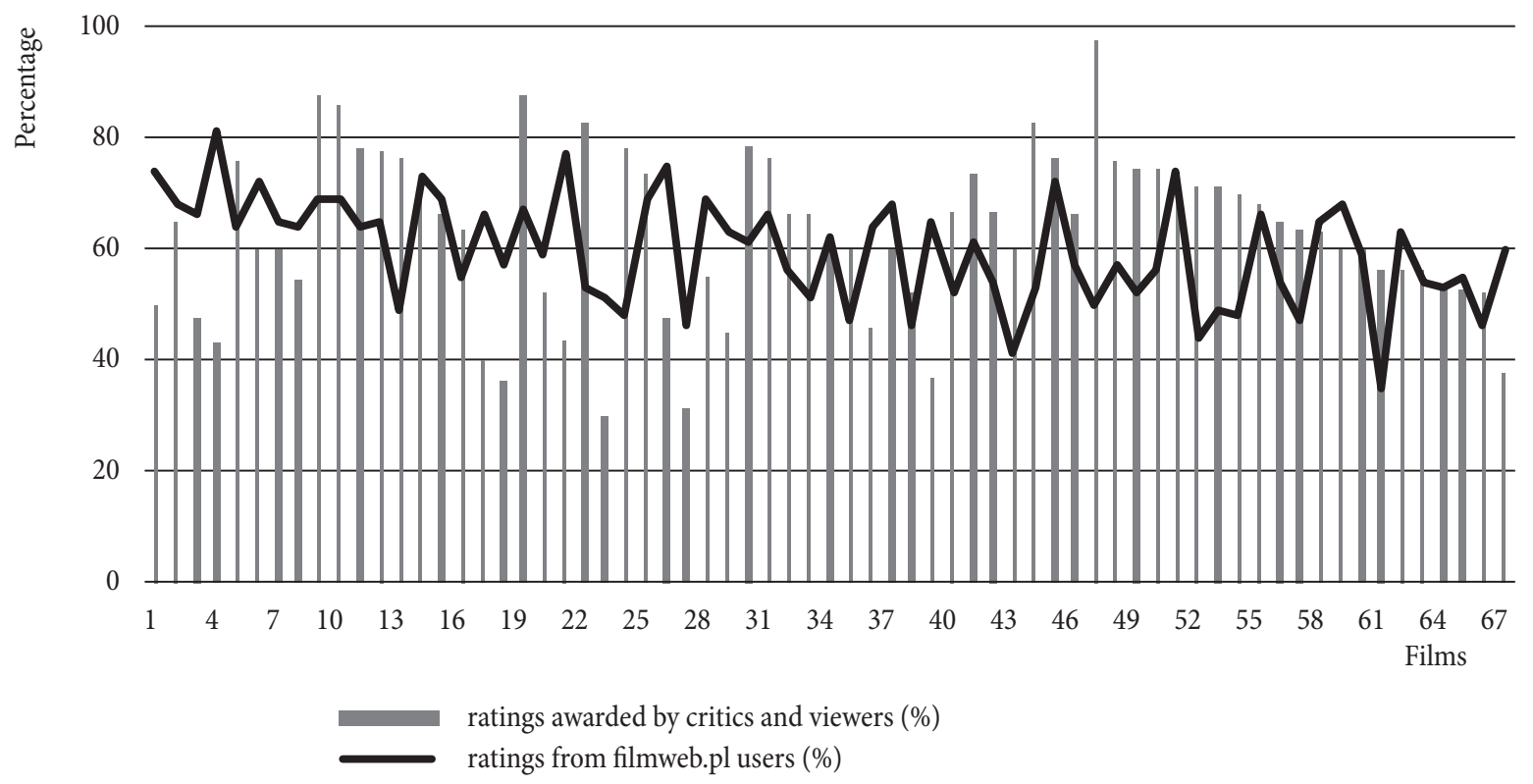

Fig. 3. Relationship between ratings from filmweb.pl users and subsidy amount 
Table 5. The 10 films with highest adjusted loss

\begin{tabular}{llclc}
\hline No. & \multicolumn{1}{c}{ Film title } & $\begin{array}{c}\text { Release } \\
\text { date }\end{array}$ & \multicolumn{1}{c}{ Director } & $\begin{array}{c}\text { Loss adjusted for } \\
\text { subsidy amount }\end{array}$ \\
\hline 1 & Papusza (Doll) & 2013 & Krzysztof Krauze, Joanna Kos-Krauze & -3546526 \\
2 & Fotograf(The Photographer) & 2014 & Waldemar Krzystek & -3274226 \\
3 & Obce ciało (Foreign Body) & 2014 & Krzysztof Zanussi & -2481515 \\
4 & Zbliżenia (Close-ups) & 2014 & Magdalena Piekorz & -2456913 \\
5 & Anatomia zła (Anatomy of Evil) & 2015 & Jacek Bromski & -2363309 \\
6 & Serce serduszko (The Heart and & 2014 & Jan Jakub Kolski & -2174174 \\
& the Sweetheart) & & & -2031635 \\
7 & Bez wstydu (Shameless) & 2012 & Filip Marczewski & -1958692 \\
8 & W ukryciu (In Hiding) & 2013 & Jan Kidawa-Błoński & -1820796 \\
9 & Córki Dancingu (The Lure) & 2015 & Agnieszka Smoczyńska & -1780395 \\
10 & Intruz (The Host) & 2015 & Magnus von Horn & \\
\hline
\end{tabular}

The next measure of success that can serve as justification for the spending public funds that is drawn from the domains of economics and effectiveness analysis of public support is the relationship between the amount of subsidies awarded to the film and its income. The index that reflects the effectiveness of public spending on film production is the picture's income adjusted for subsidy amount. In the case of most of the analyzed films, the sum granted by the Institute was higher than the revenue from sold tickets, so the index is negative. The largest revenue after adjustment for subsidy amount was grossed by the film Gods (Bogowie) directed by Łukasz Palkowski and produced by Piotr Woźniak-Starak. It is interesting to note that the largest success in terms of declared income adjusted for subsidy amount was the second feature film produced by a person who comes from "outside" of film industry circles, does not hold a degree in production, and did not go through apprenticeship with a more experienced producer. Having said that, Woźniak-Starak has considerable support in the form of his own independent capital resources as the son of one of the richest people in Poland.
The largest adjusted loss was recorded for Doll (Papusza) by Joanna Kos-Krauze and Krzysztof Krauze. This means that in case of this film the relationship between the subsidy amount and income from tickets was the smallest in the study sample. Does this mean that the film should not have been subsidized or granted such a high sum? The answer to this question is not easy. Although the numbers are merciless in showing small attendance and humble income, the critics judged the film as very good, and so did the users of filmweb.pl.

Doll is an outstanding picture that still has not been properly appreciated. The Krzysztof Krauze and Joanna Kos-Krauze duo expertly shaped the plot, presenting the story in a nonlinear fashion, with narrative jumps spanning over seven decades of the twentieth century. As a result, instead of a simple chronology, we are given a tale about the mythological structure of the world that gradually navigates from harmony and perfection to decadence and decay. In within this structure the authors have woven the destruction of gypsy culture through the forced settlement of its members by the authorities of the People's Republic of Poland, as well as the 
tale of a People's Poland that is gray and uninteresting when compared to the interwar charm of a multicultural country. The Krauzes avoid trivial contrasts and do not portray the Roma community as passive victims, choosing instead to show the universal mechanisms of exclusion, ostracism and destruction of otherness which do not spare various communities. The two main characters, Papusza and Jerzy Ficowski, are also convincingly portrayed as people who are willing to sacrifice everything for the text and live in the text, with the full awareness that literature is capable of stopping time.

We devote so much attention to Doll to show the limitations of the approach applied to the study of film in this article. Indeed, numbers are interesting and pose intriguing puzzles before us. However, sometimes there are also films that are outstanding but gain neither attendance, nor festival awards, nor critics' recognition. They do not show any "revenue adjusted for subsidy amount", quite the opposite - they make losses, while simultaneously representing a cultural gain and undoubtedly enriching the history of our cinema.

All numerical data pertaining to film requires interpretation and comment from the perspective of film studies. Without knowledge of the field it is easy to jump to incorrect conclusions and pass hasty inaccurate judgment on a picture. Drawing conclusions solely from statistics could lead to a situation in which only films expected to make financial profit are produced. Meanwhile one of the aims of the Polish Film Institute is to support precisely those pictures that are not aimed at attracting large audiences and generating income but will be of value to our culture.
On the other hand, numbers are currently the only objective indicator that allows to evaluate a film. Other measures, like opinions, reviews or awards, are subjective in nature and reflect above all the tastes of the jury members. Although, within the domain of reviews mathematics also plays an important role. One very important aspect of cultural statistics is numerically representing the ratings from professional and nonprofessional viewers. Having admitted the variability and subjectivity of the opinions of critics and viewers, quantifying their reviews enables to perform a certain classification of films and, with some simplification, gives an idea of the general reception of a given picture.

Statistics is necessary for shaping cultural politics as well as for establishing the rules for financing filmmaking from public funds. Statistical data are an important factor that impacts the actions undertaken for supporting the development of this art. We need indexes that are concrete, quantifiable, pertinent and can be calculated for a specified timeframe in order to set and carry out the goals for cultural policies in the area of film production. The objective description of the state of cinema on the national level and comparing it to the situation in other countries enables us to better consider our own position. Statistics which reflect reality allow one to evaluate the actions undertaken by state institutions and often serve as justification for public spending.

While aware that the mathematical-statistical approach to film should be applied in moderation, we remain convinced that it is a research path worth developing.

Tłumaczenie: Aleksandra Małecka 